Security beyond the men: women and their everyday security apparatus in Mathare, Nairobi

'The woman noise-maker has come, now we have no peace!' Police Officer, from an Eastlands Police Station

\title{
Introduction
}

The proliferation of urban security concerns, local and global, are layered with fears over deepening inequality, socio-spatial bifurcation, crime, and, especially in the global south context, urban renewal, urban land conflicts and 'secure urbanisation' (Lombard and Rakodi, 2016; Waquant et al, 2014; Goodfellow and Smith, 2013; Samara, 2010; Klopp, 2008; Atkinson, 2006). Concerning (in) security discourses in Africa in general and those situated in poor urban settlements in particular, however, there is a tendency to reproduce a partial and myopic focus in two senses. Most scholarly and policy treatment of security governance 'continues to miss the biggest story on the plural nature of security provisioning in African states' (CHRIPS, 2015:12). That omission concerns 'the ongoing transformation of security governance by the continuing fracturing of the state's dominance and the increasing prominence of non-state mechanisms in public security in Africa' (ibid.). The other oversight, and comprising the main focus here, occurs because security discourses have an overwhelming focus on young men, even in contexts such as the study case, which harbour a large demographic of women and children. More recent approaches do increasingly emphasise the plurality of actors in security provision (e.g. Price et al, 2016, CHRIPS, 2015). Men, however, are often the most immediately visible and perhaps more explicitly assertive protection actors as they engage in patrolling formations and attendant surveillance practices. Arguably, this 
tendency colours and defines what is conventionally understood as security and its preoccupation with masculinized force (see Sjoberg, 2010), which renders invisible the safety contributions of women, and even children. As the other core concern of the article, and perhaps in close relation to the apparent andro-centrism of security discourses, is how (in-)security elides with the political economy of urban informal settlements. The structural violence associated with deep-seated multi-layered deprivation and illegality of 'gray spaces' (Yiftachel, 2009), feeds insecurity but also, simultaneously, provides income generating activities, including the more physically coercive 'vigilante' security provision and effects of corruption upon policing, again, overshadowing women's varied contributions.

In Mathare where our paper anchors its arguments, certainly, the demographic dominance of women also contributes to the historically salient role that they have in protecting kin and community in this location. As demonstrated by White (1990), Nelson $(1995,1996$, 1997), Fredericksen (2002) and Van Stapele (2015), and very explicit during our fieldwork processes, here women are the orienting figures. Though providing critical reflections on what is often a state-centric treatment of security, neither of the aforementioned literatures adequately take up the role of women as security actors in poor urban spaces. Against this background, and comprising the main focus here, our paper foregrounds what is often an unseen yet important feature of security provision in Mathare constituency: the everyday security apparatus constituted by women. Okech (2016) argues that while debates about gender and violence have been one of the most vibrant aspects of feminist scholarship about African women, what is often lost in these analyses is the role of women beyond the position of 'victims.' Similarly, Bennett (2010) implores us to "dissolve" the dichotomies in which women are framed and that create inaccurate metanarratives about them and their lives. As White (1990) asserts piercingly in her monograph on pioneer women households in Nairobi: 'There must be some middle ground between denying male violence and overestimating it to the extent that it makes women seem 
immobile' (White 1990: 6). Our work heeds these calls to complicate the tropes about women in Africa, and particularly those in urban spaces such as Mathare. ${ }^{\mathrm{i}}$

To these ends our paper attends to the following questions: How do women live in a space that is often conjured as unliveable for them? What practices do they engage in to ensure security? What are some of the significant threats and challenges to 'security' in Mathare? We begin by detailing the major security challenges situated within complex spatial conditions shaped by a lack of service provision (water, electricity and sanitation etc.,), tenure contestations, unemployment, socio-economic rights, ethno-political fault-lines, patriarchy and generation. Following this, we discuss the safety practices of women in this area. We highlight and uphold them as important and constant features of security provision in poor urban spaces, available before and beyond the men, that when considered, situate women as key protection actors locally. We then provide coverage of the predominant powerful local undercurrents that challenge and constrain women's efforts and actions. Finally, in conclusion, we summarise and draw out the implications of our main findings.

Our data emerged primarily from mixed qualitative methods (ethnography, participant observation, interviews, three focus groups and "go alongs" (Kusenbach 2003) and one related survey. The mainstay of the data is from the three focus groups, which had in total 40 female participants, drawn from two areas of Mathare- one group comprising a local women's Chama, ${ }^{1}$ another representing sex workers, and the third also members of another Chama group. There were also some more specific follow up interviews with individual focus group members (two), and key informants (two), three of whom who identified as 'human rights defenders'. One prominent local male vigilante organisation was also interviewed (findings in Price et al, 2016 are drawn upon). We also drew upon a quantitative survey conducted by the authors with 400

\footnotetext{
${ }^{1}$ Chama is a broad Swahili word, similar to the Gikuyu kiama, which can be used to describe formations as diverse as a political party, women's church group, young men's savings collectives and other formal/informal formations which serve a variety of group functions.
} 
hundred respondents across each of the 6 wards of Mathare to gauge community perceptions of safety more broadly (see Kimari and Jones, 2016). The results of the survey made evident broad patterns of widespread local distrust of the police and 'vigilante' groups who provide security, as well as the fear of petty robbery, extrajudicial killings, fire and sexual violence (see Kimari and Jones 2016). Findings are predominantly taken from transcribed group or interview discussions, which were not coded. In terms of sampling, though we can not be certain how representative this is, the views are from a fairly large number of respondents- triangulated by consistent fieldwork in the area by both researchers over several years and supplementary sources- which we understand to be typical of the security challenges and female responses gauged, such as they have been hitherto in the literature.

\section{Key Insecurities}

At the outset of each focus group discussion ${ }^{2}$ participants were asked to identify some of the most pressing security issues they encountered as residents of Mathare. They mentioned a number of key material challenges, and it is important to emphasize that their responses represent insecurity as a multi-faceted phenomenon, closely related to broader structural dynamics. These sentiments resonate with the findings from comparative studies done elsewhere (Action Aid 2011, 2013, 2015; World Bank 2011). Indeed, the overall urban condition that permeates all facets of life in Mathare is that of so-called 'gray' spaces, namely, whose legal status pose ambiguities because they supposedly lie outside of the formal realm of law and planning (Yiftachel, 2009). Gray space is most visible in the proliferation of informal settlements, or 'slums', which are particularly vulnerable to social problems, private developers, arbitrary state policy, and oppressive policing of supposedly illegal spaces, often resulting in evictions or other unlawful infringements.

\footnotetext{
2 There were 3 groups: One conducted in Bondeni/3C area (FG2), and two (FG1 and FG3) in Village One/Mlango Kubwa area.
} 
In all three group sessions the high incidence of rape and teenage pregnancy - often connected —-were mentioned as critical security issues. One volunteer described in an interview how she is called 'each and every morning' by an organisation that works with rape victims, and consequently perceived the level of these violations to be very high in her settlement. Her observations are corroborated by literature that focuses on sexual and gender-based violence nationally (NGEC 2015; KNBS 2014; NCRC 2014; McEvoy 2012). These assaults were tied in, however, with a range of associated factors. Notably, vulnerability was perceived as closely related to participants' positions as female single parents; a situation seen to be without adequate physical protection or support in mitigating daily struggles and, therefore, increasing ones susceptibility to attack unless they themselves possessed the strength to prevent this. Elaborating on this, one participant expressed that:

Single parents in the ghetto have no one to speak for them, they don't have security. You are vulnerable and anyone can molest you because you have no one to speak for you and your child is not old enough to stand up for you. I have been brought up in the ghetto and if anyone touched my mother I could fight with 10 people (Mwikali, FG3).

This vulnerability is said to be intensified when, mostly, male ex-partners did not contribute financially or act responsibly for their children.

Another related facet was how the search for work - either selling sex, or otherwise hustling (see Kimari 2015) - meant long periods when mothers (and sometimes both parents if husband was present) had to leave their children home alone. This was identified as placing children at great risk, and especially during the night:

On the rape issue, adults are not raped unless they are completely drunk, but as parents we don't have time for our children. You will find a situation where someone has given 
birth to a girl and has to hustle so that the girl can eat. Some people hustle in small bars, others go to town and other places - there is no time to live with my child. There are some men also who drink and go round looking for people to sleep with, and so if someone has investigated and found that at this time I am not in the house, by the time I come back he will be through with whatever he wanted to do. Rape cases here mostly involve children, so it is not adults. If I have decided that I only enter the house at 11.00 pm, I sleep and I don't have time to speak to my children. So even if the child wants to tell you something she can't because she knows you don't have time for her, so there are many chances for children to be raped, but not adults (Ndinda, FG2).

And:

My name is..., and in my opinion the biggest issue here is unemployment which will make you indulge in wrong things. Things like I leave my children sleeping and go searching in town, so if you find someone telling you he has Ksh. 2,000 you will sleep with him, and this is because of the problems — because of the children you have left in the house. But if you had a husband who was responsible for those children, we wouldn't do some of these things, is it? I think that is the biggest problem. Another thing is one day we were coming from town and we found that a fire had burnt down everything. Children were removed from the house but there was nothing we were left with (Ciku, FG1).

Fire is a constant part of life in Mathare. Sometimes it is used maliciously as a tool for evictions in order to remove residents from land which can be redeveloped by landlords for higher profit, or for infrastructure projects. Either way, the persistent threat of conflagration reflects the precocity of life for residents who are dealing with multiple risks simultaneously. 
As is evident from the above excerpts, the women interviewed regarded conditions of, for example, economic precarity, single parenting, sex work and fires as linked parts of their experiences of insecurity. They also spoke about the direct correlation between the unemployment of local male youth in Mathare and the probability of them creating insecurity. In such an instance, one interlocutor shared that:

If there are job opportunities and people work, is that not ensuring security at home? So the biggest problem is poverty because if the youth get jobs, is the security not ensured here? But if there is no job, there will not be any security here. Not unless we get jobs, then there will be security. We don't even want the government to help because this is our home, we were born here and we are the ones that can ensure security is maintained. The problem is unemployment: if we are employed then the security is ensured (Eunice, FG2).

Another participant clearly linked underlying conditions to justifying her own criminal activities:

I can't look at my child sleeping hungry while there is a phone just lying there. Or I can't see a drunkard with Ksh. 500 and I know that my child is sleeping hungry so I will take it. We don't like doing it, but we just have to because of the poor lives we have. Take the father of my child as an example, he has a lot of money and if he wanted me to live well I could. But because he left me with the child will I throw the baby away? I have to take care of the child but I don't have any money, so you go and snatch so that you can feed your child (Vicky, FG1).

The lack of adequate living infrastructure also creates conditions of risk for women, and this threat is amplified by the mabati (corrugated iron sheet) houses that can be easily accessed, 
damaged, or pierced by the 'stray' bullets of police officers as has happened on more than one occasion. Furthermore, this is coupled with the absence of sanitation facilities in their immediate vicinity (see also Action Aid 2013 and Amnesty 2009). It is principally the dearth of toilets and ablution facilities, and those available are often some distance away, which requires tenants to leave their houses at inconvenient hours. The limited access to these services makes women more vulnerable to sexual assault here and in similar settlements. As one group participant exhorted:

It's an issue. I wish you were in Mathare. I have three ladies who were raped in the toilet in Mlango Kubwa. I went to chief and he said "that is not the time to go to the toilet"! I went to DO [District Officer] and he said 'but it happened at 8 pm.' That is not late! One lady [then] came with her daughter who she said was raped by three in the toilet, and she said she wanted to move from her place because the people 'who did it would kill her if they know I had gone to the chief'. And so I said I could call them here and she said no, and that I should just help her get medication and then she'd leave her house and go somewhere else (Mwikali, interview).

The pursuit of justice in all of these cases is often hampered by, as the above experience demonstrates, the unwillingness of the state administration to act on behalf of these women. In another example, Mwikali's neighbour's son was raped by a known teenage male but the police were allegedly bribed not to pursue the matter. What connects the two incidences is how any attempts to seek redress are frequently thwarted by an inequality in political citizenship compounded by an institutionalized patriarchy, and one manifestation of this is the disinterest by the local state administration and police to even receive cases of sexual violence. Corruption is also a pervasive factor: local state actors and the police are described in the local survey we 
conducted, of over 400 residents, as typically 'only wanting money' and so, because of the earning potential, 'don't want any security' and 'only come when the chaos is over.'

These reflections from the focus groups, interviews and survey make evident a number of convergences: the relationship between socio-economic precarity and situated conceptions of insecurity, and the strong connections between, for example, unemployment, child abuse, rape, fire and a lack of basic infrastructure. What is also evident from these narratives is the deficit and/or monetization of state protection services for the poor, the gendered dimensions of this neglect, as well as the fear, lack of unity and distrust that can cohere in situations rife with significant structural and symbolic violence. Therefore, in light of the consistent insecurity, what exactly do women do to ensure the safety for themselves and their community?

\section{Gendered Security Practice}

As the earlier interview excerpts convey, while women suffer greatly from the insecurity in Mathare, they were not passive victims and at times even participated in criminal or 'defensive' activity. Consider the following vignette:

Kigoma $^{3}$ and one of the authors are on their way to get tea and chapati for one of the morning focus group discussions. Stumbling through the early risers and their garrulous din they navigate the uneven Mathare terrain, ${ }^{4}$ a landscape made even more treacherous by the jagged edged rock that punctuates this narrow pathway Kigoma has deemed a 'short cut.' Before the author was able to catch her breath on Mau Mau road, still astonished that they had actually jumped off the sharp ledge without calamity, they run into Kigoma's cousin who seems intent

\footnotetext{
${ }^{3}$ All interlocutor names have been changed to protect their privacy.

${ }^{4}$ A large part of Mathare was a quarry, from the early 1920s to the late 1940s (Hake 1977; White 1990; Andvig and Baraza, 2014), and this history accounts for its hollowed out and uneven landscape.
} 
on reproaching him for the conduct of someone we shall call 'Jackie'. The conversation goes as follows:

Kigoma: How are you my cousin, how have you been?

Cousin: Good, but I need to talk to you about your friend Jackie.

Muiru: Kwani, what is going on?

Cousin: You know she has been standing outside the bar at night, [akinyonga] strangling drunkards and stealing their money. One even called me this morning crying. And I can't even tell you the words he said came out of Jackie's mouth.

Muiru: Ai, sawa. But what do you want me to tell her, she has 6 kids?!

Cousin: Just tell her something please!

It was only Kigoma's insistence that they had to go and pick up the snacks for the group discussion, which allowed them to exit this chastising.

Jackie's tale is but one in a patchwork of many that illustrates the deeply contextual, yet shifting, involvement of women in both everyday security and insecurity provision in Mathare and other poor urban settlements in Nairobi. We met many Jackies' and "cousins" throughout this research, all of whom, through their informal security and insecurity practices, belied the hegemonic binaries of African 'slum' women omnipresent in both scholarship and NGO literature, narratives which position them either as 'victims' or 'peacebuilders' (e.g ActionAid 2011). In one particularly brutal episode, for example, women in Bondeni ward pursued alleged criminals and macheted two of them to death (Van Stapele 2015). They are also often not unlikely participants in the 'mob justice' beatings and lynching that are meted out to people 
seen or suspected to have been involved in anti-community criminal activity and who have had the misfortune of being caught by a braying public. Other scenarios arise where, as one focus group participant put it, 'we wanted to castrate someone for rape with a pair of pliers'definitely not the expression of simple 'victims' and 'peacebuilders.' Nonetheless, these more spectacular and violent activities are not as frequent and pervasive as what we see as the gendered security labour that women engage in through a variety of every day practices, and which we examine below.

Our interlocutors discussed a range of actions they took up to diminish insecurity. Those less perceptible could be, for instance, sharing pertinent security information when they meettypically at Chama gatherings, at the hair salon, in church or even in the line while waiting to fill up jerry cans at the water kiosk. A prearranged meeting to discuss the spate of robberies in one compound, for example, resulted in the construction of a communal gate which restricted entry into the cluster of houses that were the targets of the burglary. The result was a dramatic decrease in the level of crime that these tenants faced, demonstrating the impact of an invisible intervention supported by a visible strategy.

Other practices include the encouragement and mobilization of young men to attend a recent baraza (meeting) they had organised with the area chief. At the meeting, attendees, the majority of whom were mothers, implored the administrator to find job opportunities for the predominantly male youth present, so that they would not enter crime and be killed. Later, one mother shared two instances where they were able to target particular groups of youth at risk of committing crime with success. She explained:

There was a certain group stealing and most have come out of that base (squad) that is now doing construction - building houses. The headmaster had a plot [piece of land] and it had lots of garbage and he called me to help him. I said to the headmaster 'don't 
call people from outside but use our boys.' They are now getting 500ksh [\$5] per day. And if they are working today and tomorrow then they are serious and too busy to steal. Also there was another incident when a phone was taken and we called the kiosk where the boys were hanging out and we said 'we don't want those boys hanging around and we will close the shop if you the shopkeeper don't do anything.' Now the shop owner has made them move and things are better now (Mwikali, interview).

Similarly,

If there are 5-10 boys in the same area they cook trouble, but we try to chase them or talk with them if we know them. We say: 'you Maureen make sure you speak with these boys I don't want this here.' We just talk with them [or their family]. Like yesterday we said "no no no!" and chased them away (Muthoni, interview).

Here, if they see groups of youth hanging around aimlessly and looking like they have the potential for criminal activity (as seen in their actions, behaviour, scoping targets, past practices etc.) then they can also have a quiet but firm word with them to move on so as to avoid incident. This approach, however, is more likely to be used if they are a relative or friend of the family.

More public interventions might involve reporting cases to the police when they felt secure enough to do so. One strategy reported to Price et al (2016) by women human rights defenders in Mathare was the use of a seemingly more accessible police officer as an intermediary, who they could then solicit to intervene on their behalf at the police station. The contact details of the particular officer were safe guarded for future use, and efforts were dedicated towards maintaining a good relationship with this person. This practice is also used with other state representatives such as chiefs and village elders, and has also been documented elsewhere (see Garmany 2014 on similar strategies in Fortaleza, Brazil). 
Furthermore, it was shared in one focus group that while many community members live in fear of the rampant police killings of 'suspects' that occur on the way to the police station, in Kiamaiko ward 'there is no way a young man could be removed from the house [by the police], women would escort him [to the station] until they are sure he has reached [safety].' There are also more visible instances where it is only the emotive pleading of older women over young men threatened with death by the police, that saves their lives that day (see also Jones et al 2017). We were told of a few examples of this, and a similar incident in Mathare during the recent 2017 post-election violence, narrated to Mwangi (2018) by a grandmother called Beatrice, is shared below.

It happened not long after the August $8^{\text {th }}$ general elections. In fact, it was on the morning of Saturday $12^{\text {th }}$ August and I was home making breakfast when this neighbor of mine storms into my house without the courtesy of a knock. She struggled to speak with bated breath. You could tell she'd been running all the way here, from her breathing pattern. I started to get nervous. She soon got started on how messed up the situation outside was, how the world was closing in on her and that she wanted to die. The police had ambushed us. They had our community area of Mathare 4A under 'Ringis' (where an entire space is completely surrounded by police officers), breaking into houses, picking out and brutally beating up our young men. For the ladies who stood in their way, they sexually harassed [them]. My neighbor's son was among the victimized young men. He was critical. 6 had been killed already, from thorough cold-blooded beating with clubs and batons and I was the only one she'd thought of running to, believing together we could help end this.

So we walked quickly outside and I start hearing the sound of heavy firepower all around me, and it's getting louder and louder. The youth had begun fighting back and 
defending their lives now. They were throwing stones in turn at these men with guns. It was tense everywhere. They had an entire village at the stake, holding their riffles against men lain on the road. And why, as am sure you're going to ask, was there all of this hullabaloo? Why were the police here bringing war on peaceful citizens awaiting announcement of election results? Here, I'll give it to you - the intention was to suppress. They'd been sent here to intimidate us. It may have been a game of psychology for them and all, but they were killing us for real. This was no game for us. Something had to be done there and then $[\ldots]$

My confrontation with the officers wasn't a walk in the park. They demanded that I ask the young men to stop throwing stones at them so they could withdraw. I called the area OCS and spoke to the youth. Both sides eased up and called off the fuss. The Red Cross team also arrived on site and tended to the situation. There was blood strewn everywhere. So many people were left injured, others were hospitalized plus we lost a total of 7 young men, with my neighbor's son succumbing to injuries. The amount of violence and inhumanity I witnessed still haunts me to this day. But this is the country we live in, and if we do nothing to change it, it's exactly where and how our children are going to live.

Even if the work they do for the safety and protection of their community is not widely considered a security practice, the power of women to intervene for protection for all, as Beatrice does in the above narrative, may be rendered more visible and called upon in critical situations as in the excerpt above. Their practices to secure community and kin, both spectacular and mundane, speak to the instinctive and multifaceted ways in which women respond to insecurity in their communities. This patchwork of everyday actions creates a security infrastructure that while often taken for granted and invisibilized, infiltrates every aspect of life 
in Mathare, and, as is seen in the example above, is called upon instinctively to provide peace and security when it is beyond the men. However, the success of these gendered efforts are not always guaranteed since there are a number of forces that work against the operationalization of these habitually women led security practices.

\section{Challenges to Security Provision}

Fear

One prominent concern expressed in the discussions, interviews and surveys was the element of fear - a strong deterrent in tackling abuses. Some respondents held that this was reflective of the overall condition of poverty and how that led to the internalization of inferiority, and, along with it, a sense of helplessness in being able to do anything about the prevailing insecurity. Evidencing this, one woman (FG1) recalled how someone broke into her shack and took two mobile phones, and while she knew the perpetrator, she felt powerless to stop him as she feared reprisal should she approach the police. In many cases - and these are inevitably shaped by ward, class, single parent status and network - it is well known that if a person was deemed responsible for reporting an incident to the chief or police, they should fear retribution since culprits were known to bribe these government representatives and could seek revenge on those who had delivered them to the authorities. Here there were limited, if any, bounties for informers. Furthermore, in some instances thieves were regarded as actively working with the police beyond paying them off (see the section on 'police and power'), and this knowledge impacted resident's willingness to seek redress from these forces. Given that the vast majority of single parents are women, fear was particularly gendered due to perceived vulnerability to retribution.

\section{Familial Bonds}


There is also the common practice of 'hiding' relatives, particularly children, who were deemed culprits by the community, but whose wrongdoing was often fervently denied by their parents. In one sense it was a logical response that families would take these young suspects in to 'exile' so that they would not be found by the police, easing, in turn, the stress of their mothers. What's more, in light of the limited economic opportunities for Mathare residents, especially its youth, there was also a shifting meanings about what really constituted 'crime.' At the same time, the lack of cooperation from the, habitually female, parent when they were approached by residents to 'talk' to their child who was suspected of wrongdoing, often a stubborn insouciance, was seen to undermine concerted efforts to mitigate insecurity and 'reform' young people. In one spectacular event, a police raid unearthed $24 \mathrm{AK} 47 \mathrm{~s}$ that one grandmother had been hiding for her three sons: such indifference from guardians reinforced fear in many residents.

The contradictory tragicomedies of their own lives, against the backdrop of deeply unequal and underserviced communities, also limit women's abilities to protect each other. The following example of 'gender-defending' by Ndunge puts this into context:

Personally, I was trained as a gender defender so it is a challenge for me because for example if someone is beaten up and I am also beaten up and I am supposed to defend them, the work is in my heart but really it doesn't work. I listen to so many cases of rape, domestic violence and others. I take the children to the Children's Officer in Kariokor. At the same time, I also live in the ghetto and I am hustling, I don't have any employment. So even when I take the case to Pangani [Police Station], I leave it there because I won't even have bus fare to proceed, so I just leave the cases hanging. So it is a challenge for me on the ground because of lack of resources, and so you can't move far. Also if I fight with my husband and I go to the chief's office, he asks if I am a gender defender and tells me to defend myself! (Ndunge, FG2). 


\section{Police and Power}

One of the major obstacles to creating common strategies and united interventions against insecurity is the nature of the political economy of the slum itself. Over many years areas like Mathare have not been regulated urban spaces but rather ones prone to the informalization of service provision (see Andvig and Baraza 2014; Thieme 2013; Medard 2010). This condition essentially renders these settlements market places, where everyone hustles for a slice of the earnings available. Yet, whatever profits exist, and these can be considerable,- - based on illegal alcohol brewing in particular, drugs and land speculation - they tend to be monopolised by wealthier patrons who don't live in the area. And the people who control the most lucrative services are seen as above, if not even making, the law:

There are owners of the ghetto; you don't want to mess with them. A single call from him causes chaos. Even if we were born here, we are not the owners; we are just stepping on their soil. The big bosses control the illicit brew, and even own the valuable businesses. We are just small fish in the big pond (Gathure, FG2).

This power was manifest everywhere in the landscape, and one of the most profitable and highly politicized expressions of this elite control is land grabbing (see Klopp 2008; Medard 2010; Obala and Mattingly 2014). The endemic and conjoined phenomena of land grabbing and evictions are a catalyst for insecurity as tenants live under the constant threat of looming displacement. The following interview excerpt powerfully reinforces the tendency of money to 'bend' decision-making and influence authorities, and demonstrates how better placed individuals can therefore take advantage of informality:

The main problem is that there is no way that someone can just claim this is their place and fence it without the chief knowing about it. That's why the government is involved; 
so the people who are supposed to protect you are the ones destroying you. That's how you find that a [business] woman tells you to just move out and not peacefully. You can come and find it is burnt or you find me killed in the house because they know I am a loud mouth and I won't move willingly. The chief, DO, village elders, land and settlement officials all know about it. When the chief came here I spoke with a lot of pain because I am 30 years old, my father was born here in 1952. My grandmother came here when she was 13 years during the colonial times, was married and gave birth to my father in 1952. I was born here and I have a 14 year old boy, how do you think I can get out of here? I have no documents, but the chief, DO, and other people who know my background have already disowned me because I don't have anything to give them. Even when the road [constructed since through the entire length of the valley] was being built, houses were demolished and no-one could speak. The government is also corrupt because the chief and village elders are on the rich woman's side. I have the power to speak by mouth but when we go back to the office they ask me for the documents. And I will not have any because my parents are dead, so I just move (Esther, FG2).

Acute competition for land and regulatory failures, not least tenure (in)security, means land conflicts (Lombard and Rakodi, 2016) represent the most significant structural issue underpinning so much of the uncertainties of life in Mathare. The account above is a graphic illustration of the effects of long-term exclusion from city services, and makes apparent how personalised economic interests can steer authorities away from acting in the interests of poor residents, thus exacerbating their insecurity. It also is a reminder that women are not a homogenous group, and may have competing needs, as illustrated by the wealthier women exerting her influence. 
This political economy also shapes local planning decisions on, for example, water connections and garbage disposal, and, not least, the emergence of and solutions to crime. Accordingly, postings to Pangani police station close to the entrance of Mathare are deemed popular because of the potential to earn additional money from bribes and corruption - informal 'taxes' from alcohol brewing and other forms of protection for the 'big fish.' Many women are involved in the illegal alcohol business - whether producing or selling, which makes them particularly vulnerable to police bribes. In one instance, a wealthy individual was able to grab land and demolish the only public toilet for a community of hundreds; the police stood by and did not act to prevent it. Because of the probability of such incidents occurring, research participants desired a means of reporting incidents that could by-pass corrupt local institutions such as the chief and the police.

Examples were also given of wealthier individuals using the police to settle scores, whether with business rivals or problematic youth, or to expand their business interests. The cases provided earlier of house evictions, as well as the demolition of the toilet, evidence this trend (see other examples of this in Klopp 2008 and Medard 2010). At the same time, the police were also regarded as, at times, working with criminals, and therefore, feigning commitment to security by coming to the scene long after the former had departed. Worse still, the police are infamous for their extrajudicial executions of predominantly young men (See MSJC 2017). These killings are conducted even in broad daylight, in front of family members and neighbours and often without proof of any actual crime committed by the victims or situation that would warrant such heavy handedness (IMLU 2016; Jones et al 2017. Equally, with regards to nonstate security actors popularly known as 'vigilantes' or gangs, akin to the local relationship with the police, a climate of both trust and distrust and fear and hopefulness shapes their oscillating relations with Mathare residents (see survey results, Kimari and Jones, 2016; Van Stapele 2015; Price et al 2016; Andvig and Baraza 2014; Henningsen and Jones 2013). 


\section{Conclusion}

It is in some ways no surprise that communities that have been left off the map for so long would not have adequate attention directed to the myriad of complex and gendered security processes that sustain life here. This speaks to the decades of 'territorial stigmatization' (Wacquant et al 2014) that frames socio-spatial life in such geographies, but largely to a scholarly and policy preoccupation with positioning poor urban women as either victims or peacebuilders. In this paper we have sought to undermine such a simplistic binary. As the main contribution, we did this by highlighting the often invisible security work women engage in and that we argue is as important, if not more pervasive and longstanding, as the protection work taken up particularly by young men in Mathare, and other poor urban settlements in Nairobi. Theirs is both an intimate and public security, intangibly concrete, that sutures the gendered emotional, political, economic and socio-cultural labours of this space. In this geography where the overwhelmingly male police force and 'vigilante' groups are at once welcomed and distrusted (Kimari and Jones 2016; Price et al 2016), the consistent security infrastructure enabled by women allows for a reliable safety net which, while not always adequate in the face of the normalization of gross violations, contributes to everyday security provision. It perhaps follows that the dominant discourses on security connote physical coercion and means of deterrence, which these women do not possess and, as a result, undervalues their interventions. The question remains, however, even if it can be accepted that womens' contributions are under-recognised -hence our use of the term 'invisible'- can these varied activities be said to constitute 'security'? In other words, the activities (with some few exceptions) represent nonphysical means, centred mainly upon invoking and building social relations. Moreover, we conclude, following authors such as Sojberg (2010), that it is the term 'security' that is perhaps too narrow. 'Security' in its narrow meaning, fails to capture broader aspects concerning 
gendered political participation, social relations and socio-economic inequalities, which women capture so vividly in their accounts and in their efforts, no matter how imperfectly, to mitigate insecurity.

As the voices we have shared above indicate, this is not easy work or always safe. But women, for all the difficulties, do intervene to ensure protection for all. Even if a quiet word to youth, a bold plea in public meetings, the cautionary counselling of a mother or neighbour to children to avoid certain areas and even the ultimate self-sacrifice when they intervene in the near fatal threats from the police women show a diversity of tactics in mitigating insecurity. The findings also, however, qualify any simple dichotomy of men as perpetrator and woman as victim, as well as the idea that security provision always needs to be 'rules-based.'

Nonetheless, our findings also convey the multiple forces that prevent the success of their concerted efforts; a combination of fear, familial obligations and the manifestations of a political economy that enables a violent elite jostling for Mathare resources. Most disconcertingly of all, many respondents simply were resigned to helplessness and expressed a desire to leave if they had the means to relocate. Ultimately, despite the complexities and challenges, residents expressed a strong desire to better circumstances and opportunities for their children so as to alleviate what they themselves had gone through. In this regard, there is the recognition from findings, including survey (Kimari and Jones, 2016), that it is only with socio-economic improvement that security will improve drastically, and when it does this will also create less risk for women to advocate for more comprehensive community security.

Certainly the modes in which women intervene differ from ward to ward, and these situated strategies are shaped by the socialities reproduced by the descendants of the early twentieth century female urban pioneers in the east of Nairobi (White 1990; Fredericksen 2002). As mentioned, women are not therefore an homogenous group, and can be said to have 
a broad range of roles and interests. An additional significant theme to emerge is therefore that some of these interests perpetuate insecurity, which adds complexity to the gendered nature of security and, again, any sense of straight forward binaries. Nonetheless, gender as a power structure still frames and provides obstacles to their agency as women. Via discussing local events, being 'loud mouths' at the police station, hiding children, emotive pleading, sending 'boys' away, talking to 'girl's, dreaming of using pliers on rape suspects and intervening at critical moments during the recent post-election violence, they consistently recreate a constant security architecture. Any attempt to imagine safer cities must recognise and negotiate the full spectrum of actually existing mechanisms people take up on a daily basis to feel protected. In this community where many men are gone and young males are targeted, they are relentless. Therefore, any research or policy work which interrogates, for example, local non-state urban security formations must recognise the work women engage in, their mundane activities in a situation where 'people must constantly anticipate, assert, re-negotiate, and adapt their position within a volatile environment' (Price et al 2016). Their everyday security apparatus challenges us to rethink not only the hegemonic binaries that govern discourse on urban women and (in) security, but also a broader conception of security itself that urges us to direct our gaze beyond the men.

\section{References}

ActionAid International (2011) Women and the City: Examining the Gender Impact of Violence and Urbanization. A comparative Study of Brazil, Cambodia, Ethiopia, Liberia and Nepal. Johannesburg: ActionAid.

ActionAid International (2013) Women and the City II: Combatting violence against women in public spaces - the role of public services. Johannesburg: ActionAid. 
ActionAid International (2015) Women and the City III: A Summary of Baseline Data on Women's Experience of Violence in Seven Countries. Johannesburg: ActionAid.

Amnesty International (2009) The Unseen Majority: Nairobi's Two Million Slum Dwellers. London: Amnesty International.

Andvig, J., and Barasa, T. (2014) A Political Economy of Slum Spaces: Mathare Valley. Oslo: Norwegian Institute of International Affairs (NUPI).

Atkinson, R. (2006) Padding the Bunker: Strategies of Middle-class Disaffiliation and Colonisation in the City, Urban Studies April, 43: 819-832.

Bennett, Jane (2010) Circles and circles: Notes on African feminist debates around gender and violence in the C21, Feminist Africa 14: 21-47.

Centre for Human Rights and Policy (2015) Effectiveness of Community-Led Security Mechanisms in Urban Eastern Africa: A Research Agenda. Nairobi: CHRIPS.

Feuerschutz, S. (2012) Gender and Urban (In) Security in Fragile and Conflict-Affected States. Ottawa: The North-South Institute.

Fredericksen, B. F. (2001) African women and their colonization of Nairobi: Representation and Realities, Azania 36-37(1): 223-234.

Garmany, J. (2014) Space for the State? Police, Violence and Urban Poverty in Brazil, Annals of the Association of American Geographers 104(6): 1239-1255.

Goodfellow, T. and Smith, A. (2013) From Urban Catastrophe to 'Model' City? Politics, Security and Development in Post-conflict Kigali, Urban Studies, November. 50(15): 3185-3202. 
Henningsen, E., and Jones, P. S.(2013) What kind of hell is this! Understanding the Mungiki movement's power of mobilisation, Journal of Eastern Africa Studies 7(3): 371-388.

Jones, P.S., Ramakrishnan, K.and Kimari, W. (2017) Only the People can defend this struggle: The Politics of the Everyday, Extrajudicial Executions and Civil Society in Mathare, Kenya, Review of African Political Economy (forthcoming).

Kenya National Bureau of Statistics (KNBS) (2014) Kenya Demographic and Health Survey: Key Indicators 2014. Nairobi: KNBS.

Kimari, W. (2015) Humble Living and Hustling: Youth struggles in Mathare Constituency, Nairobi, in African Youth Cultures in a Globalised World: Challenges, Agency and Resistance, (Eds.) Ugor, P. and Mawuko-Yevugah, 1. 111-126. Abingdon: Routledge.

Kimari, W., and Jones, P. (2016) The Insecurities of Security Provision in Nairobi's Margins. Plural Security Insights. http://pluralsecurityinsights.org/insecurities-security-provisionnairobis-margins/.

Klopp, J. (2008) Remembering the Destruction of Muoroto: Slum Demolitions, Land and Democratisation in Kenya, African Studies 67 (3): 295-314.

Kusenbach, M. (2003) Street Phenomenology: The Go-along as Ethnographic Research Tool, Ethnography 4(3): 455-485.

Independent Medical Legal Unit (IMLU) (2016) Report on Deaths from Police Bullets from January to December 2015. Nairobi: IMLU.

Lombard, M. and Rakodi, C. (2016) Urban land conflict in the Global South: Towards an analytical framework, Urban Studies, Vol. 53(13) 2683-2699.

Mathare Social Justice Centre (MSJC). 2017. Who is Next? A Participatory Action Report Against the Normalization of Extrajudicial Killings in Mathare. Nairobi: MSJC. 
McEvoy, C.(2012) Battering, Rape and Lethal Violence. A Baseline of Information on Physical

Threats against Women in Nairobi. Geneva: Small Arms Survey, Graduate Institute of International and Development Studies.

Medard, C. (2010) City Planning in Nairobi: The Stakes, the People, the Sidetracking, In Nairobi Today: The Paradox of a Fragmented City, (Eds.) H. Charton-Bigot and D RodriguezTorres, 25-60. Nairobi: Institute Français de Recherché en Afrique (IFRA).

Mwangi, Wyban. (2018). There is a fire in the valley. The Elephant, March 15 2018. Available at: https://www.theelephant.info/reflections/2018/03/15/there-is-a-fire-in-the-valley/

National Crime Research Centre (NCRC) (2014) Gender Based Violence in Kenya. Nairobi: National Crime Research Centre.

National Gender and Equality Commission (NGEC) (2015) Keeping the Promise End GBV Campaign: Duty Bearers Handbook. Nairobi: National Gender and Equality Commission.

Nelson, N. The Kiambu Group: A Successful Women's ROSCA in Mathare Valley, Nairobi (1971 to 1990), in Money-Go-Rounds: The Importance of Rotating Savings and Credit Associations for Women,(Eds.) Ardener,S. and Burman, S., 49-69. Oxford/Washington D.C: Berg.

Nelson, N.(1997) How Women and Men Got By and Still Get By (Only Not So Well): The Gender Division of Labour in a Nairobi Shanty-Town, in Cities in the Developing World: Issues, Theory, and Policy, (Ed.) Gugler,J. 156-170. Oxford University Press: Oxford.

Obala, L. M. and Mattingly, M. (2014) Ethnicity, corruption and violence in urban land conflict in Kenya, Urban Studies 51 (13): 2735 -2751.

Okech, A.(2016) Gender and Security in Africa. Accra: African Women's Development Fund.

Price, M., Albrecht, P., Denney, L., Colona, F. and Kimari, K. (2016) Hustling for Security: managing plural security in Nairobi's urban settlements. The Hague: Plural Security Insights. 
Robertson C.(1997) Trouble Showed the Way: Women, Men, and Trade in the Nairobi area, 1890-1990. Bloomington: Indiana University Press.

Samara, T. R (2008) Policing Development: Urban Renewal as Neo-liberal Security Strategy, Urban Studies, 47(1) 197-214, January 2010.

Sjoberg, L. (2010) Gender and International Security. Feminist Perspectives. Routledge: London and New York.

Thieme, T. (2013) The "hustle" amongst youth entrepreneurs in Mathare's informal waste economy, Journal of Eastern African Studies 7(3): 389 - 412.

Van Stapele, N. (2015) Respectable 'Illegality': Gangs, Masculinities and Belonging in a Nairobi Ghetto. PhD Dissertation., University of Amsterdam.

Wacquant, L., Slater, T. and Borges Pereira, V. (2014) Territorial Stigmatization in Action, Environment and Planning A 46 (6): 1270-1280.

World Bank (2011) Violence in the City: Understanding and Supporting Community Responses to Urban Violence. Washington, DC: The World Bank.

White, L. (1990) The Comforts of Home: Prostitution in Colonial Nairobi. University of Chicago: Chicago.

\footnotetext{
${ }^{i}$ Mathare habitually refers to approximately 250,000 thousand people occupying the greater part of Mathare Constituency, composed primarily of 'shanty' dwellings and working class stone housing, and that was historically
} 
the quarry area. The constituency is made up of six wards; Mlango Kubwa, Huruma, Mabatini, Hospital, Ngei and Kia Maiko. Our research enterprise included all of these wards. 